\title{
Role of the foliar fertilization treatments on quality attributes of sweet cherry fruits (Prunus avium)*
}

\author{
Erdal AĞLAR ${ }^{1}$, Onur SARAÇOĞLU
}

${ }^{1}$ Cumhuriyet Üniversitesi Suşehri Timur Karabal Meslek Yüksekokulu, SivAS

${ }^{2}$ Gaziosmanpaşa Üniversitesi, Ziraat Fakültesi, Bahçe Bitkileri Bölümü, TOKAT

*This work was supported by the BAP (Project Number: STKMYO 005) of Cumhuriyet University.

Alınış tarihi: 2 Mart 2018, Kabul tarihi: 7 Mayıs 2018

Corresponding author: Onur SARAÇOĞLU, e-posta:onur.saracoglu@gop.edu.tr

\begin{abstract}
This study was carried out in a cherry in 2017 in Suşehri, Sivas. Eight -years old "0900 Ziraat” sweet cherry trees grafted on MaxMa 14 rootstocks were used as the plant material of the study. In the study, per 100 liters of water 250 gram of Azro select, a foliar fertilizer which contains $35 \%$ potassium and 5\% nitrogen, and per 100 liters of water 200 gram of Zinc salt (Zinc Sulphate Hepta Hydrate) foliar fertilizer, which contains $22 \%$ Zinc, were applied. The treatment was done twice: first, at the end of blooming, second, 15 days after the first treatment. As a result of the study, fruit weight, size, fruit firmness, SSC and vitamin C values of fruits obtained from potassium treated trees were significantly higher whereas fruit color values were lower. However, the effect of potassium on the titratable acidity values was not significant. With zinc application, while statistically significant increase in the fruit size, SSC and vitamin $C$ values have not occurred, the highest values in terms of flesh firmness, fruit color and titratable acidity were recorded in the sweet cherries treated with zinc. The combination of zinc and potassium led to an increase in fruit weight, fruit size, SSC and titratable acidity, and decrease in vitamin $\mathrm{C}$ and color values.
\end{abstract}

Key words: Sweet cherry, color, firmness, fruit mass, soluble solids, vitamin C
Kiraz (Prunus avium) meyvelerinin kalite özellikleri üzerine yaprak gübresi uygulamalarının rolü

Öz

Çalışma 2017 yılında Sivas'ın Suşehri ilçesinde yapıldı. Çalışmada bitkisel materyal olarak MaxMa 14 anacı üzerine aşılanmış sekiz yaşındaki 0900 Ziraat çeşidine ait ağaçlar kullanıldı. Çalışmada \% 35 potasyum \% 5 azot içeren Azro select adlı yaprak gübresi 100 litre suya 250; \% 22 çinko içeren çinko tuzu (Çinko Sülfat Hepta Hidrat) yaprak gübresi 100 litre suya 200 gram gübre oranında uygulandı. Uygulanma, çiçeklenme sonu ve ilk uygulamadan 15 gün sonra olacak şekilde iki kez yapıldı. Çalışma sonucunda, potasyum uygulanmış ağaçlarda elde edilen meyvelerin ağırlığı, boyutları, meyve eti sertliği SSC ve vitamin $C$ değerleri önemli derecede daha yüksek iken, meyve rengi değerleri ise daha düşüktü. Ancak titreedilebilir asitlik değerleri üzerine potasyumun etkisi önemli değildir. Çinko uygulaması ile meyve büyüklügü̈, SSC ve vitamin C değerlerinde istatistiksel anlamda önemli bir artış meydana gelmezken, meyve eti sertliği, meyve rengi ve titreedilebilir asitlik bakımından en yüksek değerler çinko uygulamasina ait meyvelerde kaydedildi. Çinko ve potasyum kombinasyonu meyve ağırlı̆̆ı, meyve boyutlar, SSC ve titre edilebilir asitlik değerlerlerinde etkinin artmasına, vitamin $C$ ve renk değerlerinde ise etkinin azalmasına neden olmuştur.

Anahtar kelimeler: Kiraz, renk, sertlik, meyve ağırlığı, suda çözünebilir kuru madde, C vitamini 


\section{Introduction}

Cherry is one of the most valuable fruit species accepted by consumers because of its quality characteristics, low calorie content and its high bioactive compounds content such as antioxidants and phenolic compounds and, hence, cherry production is increasing year by year.

The fruit quality characteristics and chemical composition affecting the consumer preferences in cherries vary according to ecological factors such as climate and soil, rootstock and variety used, and cultural processes such as irrigation, fertilization and pruning. However, high-yield and high-quality fruit is possible when the plant sufficiently receives the nutrients functioning in all metabolic events.

Plant nutrients are actively involved in plant physiology: structure, energy metabolism, enzyme activity, and electron transport. Each nutrient element has different functions in the plant and the deficiency of a certain nutrient element can not be eliminated by another nutrient element (Durner, 2013).

Potassium and zinc, which have significant effects on fruit yield and quality, are nutrients that agricultural soils lack often. Potassium is a macro nutrient that acts as a catalyst and an enzyme activator in many reactions in protein and carbohydrate metabolism. Potassium, which plays a role in physiological processes such as osmotic regulation, cell division and growth, neutralization of organic acids, starch and sugar formation, protein synthesis and transport of sugars and photoassimilates (Liu et al., 2000), often increases quality of the fruit and resistance of plant against diseases. Previous studies have reported that potassium treatment improves fruit color, fruit size (Tiwari, 2005) and acidity (Alva et al., 2006) in orange fruit. Lester et al. (2010) found that potassium leaf treatment increased fruit yield, sugar and ascorbic acid content in sweet oranges and mandarins.

It is estimated that the deficiency of zinc is seen in approximately $30 \%$ of the world agricultural soils (Alloway, 2008). Zinc is an essential nutrient element that affects many physiological, vegetative and generative processes in plants (Marschner, 2011). Zinc, which functions as a cofactor in the structure and function of many enzymes (Jeffery et al., 1984; Hacisalihoglu et al., 2003; Andreini and Bertini, 2012), plays a vital role in various processes such as photosynthesis, regulation of carbohydrate metabolism and regulation of phytohormones (Hacisalihoglu et al., 2001; Krämer and Clemens, 2006; Al- loway, 2008; Broadley et al., 2007; Gupta et al., 2011).

Pandey et al. (2006) reported that pollen germination and pollen tube development were greater with zinc treatment.It has been determined that zinc application increased the fruit set in hazelnut (Solar and Stampar, 2000), cherry (Usenik and Stampar, 2002) and walnut (Keshavarz et al., 2011). Zinc deficiency causes decrease in leaves, shoots and photosynthesis rate and hence, it affects yield and quality on fruit trees (Wang and Jin, 2005; Yan et al., 2010). Foliar zinc treatment in date palm, oranges and apples can significantly increase the zinc concentration, fruit yield and quality (Rodríguez et al., 2005; Neilsen et al., 2005; Khayyat et al., 2007; Zhang et al., 2013).

The effects of plant nutrient elements on cherry cultivation have been determined in many studies. Potassium and zinc, which are what agricultural soils lack frequently, are one of these nutrients. Although the individual positive effects of nutrient elements are known when they are used in sufficient quantities, it is not known how their effects will occur when they are used together. The main purpose of this study was to determine the effects of alone and combined potasium and zinc treatments on fruit quality in sweet cherry.

\section{Materials and Methods}

\section{Plant material and experimental design}

This study was carried out in a cherry in 2017 in Suşehri, Sivas. Eight-years old "0900 Ziraat" sweet cherry trees grafted on MaxMa 14 rootstocks were used as the plant material of the study. As a result of soil analysis in the orchard, potassium and zinc deficiencies were detected.

In the study, per 100 liters of water 250 gram of Azro select, a foliar fertilizer which contains 35\% potassium and 5\% nitrogen, and per 100 liters of water 200 gram of Zinc salt (Zinc Sulphate Hepta Hydrate) foliar fertilizer, which contains $22 \%$ Zinc, were applied. The treatment was done twice: first, at the end of blooming, second, 15 days after the first treatment. The study was laid out as three repetitions according to randomized complete-block design and there were 3 trees in each repetition. In the study, four different treatments were performed: potassium, zinc, a combination of potassium and zinc and control (only water). At the harvest time, 100 fruits from each tree were harvested to use in measurements and analyzes. 


\section{Fruit mass and sizes}

For each repetition, the weights of 50 fruits were determined by weighing with a digital scale with a sensitivity of $0.01 \mathrm{~g}$, and diameters of the 20 fruits obtained from the same repetition were measured with a digital caliper with a sensitivity of $0.01 \mathrm{~mm}$.

\section{Color characteristics and firmness}

Fruit colors were measured using a colorimeter (Minolta, model CR-400, Tokyo, Japan) which provided CIE $\mathrm{L}^{*}, \mathrm{a}^{*}$ and $\mathrm{b}^{*}$ values. The chroma and hue angle values were calculated with the formula $\mathrm{C}^{*}=$ $\left(a^{*} 2+b^{*} 2\right) 1 / 2$, and $h^{\circ}=\tan -1 b^{*} / a^{*}$. Texture Analyzer, TA-TX Plus (Stable Microsystems, Godalming, UK), operating at a penetration speed of $10 \mathrm{~mm} \mathrm{~s}^{-1}$ and a penetration depth of $3 \mathrm{~mm}$, fitted with a 2.0 $\mathrm{mm}$ penetrometer probe, was used to measure flesh firmness $\left(\mathrm{N} \mathrm{mm}^{-1}\right)$. Flesh firmness results were the average of 10 measurements in each replication.

\section{SSC, titratable acidity and vitamin $\mathrm{C}$}

SSC was measured with a digital refractometer (PAL1, McCormick Fruit Tech., Yakima, Wash) and expressed as percent. For titratable acidity, $10 \mathrm{ml} \mathrm{ex-}$ tract was taken from each sample, $10 \mathrm{ml}$ distilled water was added and the value corresponding to consumed sodium hydroxide $(\mathrm{NaOH})$ during the titration with $0.1 \mathrm{~mol} \mathrm{~L}^{-1}$ sodium hydroxide to increase the $\mathrm{pH}$ of samples to 8.1 was expressed in malic acid equivalent (g malic acid $100 \mathrm{~g}^{-1}$ ). For vitamin $\mathrm{C}$ content, sufficient amount of extract was taken and volume was completed to $5 \mathrm{~mL}$ with the addition of $0.5 \%$ oxalic acid. Ascorbic acid test strip (Catalog no: 116981, Merck, Germany) was taken from reclose tube, dipped into the solution for $2 \mathrm{~s}$ and reflectometer set (Merck RQflex plus 10) was started. The test strip was then shaken off to remove excess liquid over it, waited for $8 \mathrm{~s}$ and reading was performed until the end of 15 th second. The resultant value was expressed as mg $100 \mathrm{~g}^{-1}$.

\section{Statistical analysis}

The normal distribution of the data obtained from the experiment was determined by the KolmogorovSmirnov Test. The Levene test was used to check the homogeneity of group/subgroup variances. After analysis of the data by variance analysis, the significance levels between the treatments were determined by Duncan multiple comparison test. Statistical analyzes were performed in the SAS package program (SAS 9.1 version, USA).

\section{Results and Discussion}

Fruit size, fruit color and flesh firmness in sweet cherry are significant characteristics that affect marketing. It is known that plant nutrients and growth regulators have a significant effect on vegetative growth and fruit yield and quality of fruit species. Potassium and zinc are important nutrients that affect fruit quality characteristics. As a result of the study we have done, potassium application increased the size of the fruit and the fruit firmness, while it had a negative effect on the fruit coloring. It has been determined that the effect of zinc application on fruit size is not significant compared to control application. However, it was determined that the coloring of the fruit applied zinc is beter, and effect of zinc application on fruit firmness is statistically significant. The combination of potassium and zinc has caused increasing values of fruit size and fruit firmness, but it has caused decreasing values of fruit color (Table 1 and 2).

In the study, changes in properties such as fruit size, flesh firmness and fruit color with potassium treatment can be explained by potassium's role in physiological processes such as osmosis, cell division and growth and protein synthesis (Liu et al., 2000). As a matter of fact, Tiwari (2005) reported that potassium application increased fruit color and size in oranges.

Table 1. Fruit mass, fruit sizes and firmness of sweet cherry fruits (Prunus avium) affected by foliar fertilization treatments

\begin{tabular}{ccccc}
\hline Treatments & \multicolumn{4}{c}{ Quality characteristics } \\
\hline Mass $(\mathrm{g})$ & Width $(\mathrm{mm})$ & Length $(\mathrm{mm})$ & Firmness $(\mathrm{N})^{*}$ \\
\hline $\mathrm{K}$ & $7.75 \mathrm{~b}$ & $21.19 \mathrm{~b}$ & $21.01 \mathrm{~b}$ & $34.13 \mathrm{c}$ \\
$\mathrm{Zn}$ & $8.96 \mathrm{a}$ & $22.46 \mathrm{a}$ & $22.25 \mathrm{a}$ & $49.93 \mathrm{a}$ \\
$\mathrm{Zn}+\mathrm{K}$ & $8.12 \mathrm{~b}$ & $21.43 \mathrm{~b}$ & $21.19 \mathrm{~b}$ & $40.47 \mathrm{~b}$ \\
\hline
\end{tabular}

* The scale ranges from 0 to 100 for very soft to very firm surfaces. $n=60$ for the firmness (three replications $\mathrm{x}$ ten fruits $\mathrm{x}$ two different measurements for each fruit). $n=60$ for the mass and fruit sizes (three replications $\mathrm{x}$ twenty fruits) 
Table 2. Color characteristics of sweet cherry fruits (Prunus avium) affected by foliar fertilization treatments

\begin{tabular}{cccc}
\hline \multirow{2}{*}{ Treatments } & \multicolumn{3}{c}{ Color characteristics } \\
\cline { 2 - 4 } & $\mathrm{a}^{*}$ & Chroma & Hue angle \\
\hline Control & $32.41 \mathrm{~b}$ & $34.58 \mathrm{~b}$ & $19.79 \mathrm{~b}$ \\
$\mathrm{~K}$ & $29.53 \mathrm{c}$ & $31.15 \mathrm{c}$ & $17.75 \mathrm{~b}$ \\
$\mathrm{Zn}$ & $35.65 \mathrm{a}$ & $39.57 \mathrm{a}$ & $24.71 \mathrm{a}$ \\
$\mathrm{Zn}+\mathrm{K}$ & $30.19 \mathrm{c}$ & $32.20 \mathrm{c}$ & $18.50 \mathrm{~b}$ \\
\hline
\end{tabular}

$\mathrm{n}=60$ for the color characteristics (three replications $\mathrm{x}$ ten fruits $\mathrm{x}$ two different measurements for each fruit). Means in columns with the same letter do not differ according to Tukey's test at $\mathrm{P}<0.05$.

The important role of zinc, which functions as a cofactor in the structure and function of many enzymes (Jeffery et al., 1984; Hacisalihoglu et al., 2003; Andreini and Bertini, 2012), in various processes such as photosynthesis, carbohydrate metabolism and regulation of phytohormones (Hacisalihoglu et al., 2001; Krämer and Clemens, 2006; Alloway, 2008; Broadley et al., 2007; Gupta et al., 2011) can justify the influence of zinc on fruit quality characteristics in the study. As a matter of fact, Rodríguez et al. (2005); Neilsen et al. (2005); Khayyat et al. (2007); Zhang et al. (2013) have reported that zinc application can significantly improve fruit yield and quality in date palm, oranges and apples.

In the study, SSC and vitamin C ratios were significantly higher in fruits obtained from the trees treated with potassium compared to other treatments. However, it was found that the effect of potassium was not significant when compared to control with respect to titratable acidity values (Table 3). Contrary to the results of the study, Alva et al. (2006) reported that potassium application caused an increase in the titratable acidity in orange fruit. However, Lester et al. (2010) have determined that the potassium foliar fertilizer increased fruit yield, sugar and ascorbic acid content in sweet oranges and mandarins. In the study, the highest titratable acidity values were obtained with zinc application whereas there was no significant difference between zinc application and control application in terms of SSC and vitamin $\mathrm{C}$ values (Table 3 ). In previous studies, it has been determined that zinc foliar fertilizer increases fruit yield and physico-biochemical quality of fruits in "Washington Navel" orange (Dawood et al., 2001) "Balady"(El-Baz, 2003) and "Kinnow" (Razzaq et al., 2013) mandarins. Khayyat et al. (2007) reported that, foliar spraying of zinc sulfate could increase palm fruit yield and fruit quality; and foliar spraying of zinc sulfate before budbreak of apple trees significantly increased the contents of soluble sugar, vitamin $\mathrm{C}$ and fruit firmness (Hafez and ElMetwally, 2007; Zhang et al., 2013).

In the study, the highest fruit weight, fruit size, SSC and titratable acidity values were recorded with zinc and potassium combination. There was no statistically significant difference between zinc, the combination of potassium $\mathrm{x}$ zinc and control treatments in terms of vitamin $C$ values. Due to the adverse effect of potassium, the combination of potassium and zinc has reduced the color values. Ashraf et al. (2012) have determined that potassium $\mathrm{x}$ zinc foliar fertilizer increases SSC content of "Kinnow" mandarins (similar with our study results) and vitamin $\mathrm{C}$ content (contrary to the results of the study). Hafez and El-Metwally (2007) and Eman et al. (2007) reported that potassium $\mathrm{x}$ zinc foliar fertilizer significantly increased fruit weight in Washington Navel oranges.

Table 3. Biochemical characteristics of sweet cherry fruits (Prunus avium) affected by foliar fertilization treatments

\begin{tabular}{cccc}
\hline Treatments & \multicolumn{3}{c}{ Biochemical characteristics } \\
\hline & SSC & $\begin{array}{c}\text { Titratable acidity } \\
\left(\text { mg malic acid } 100 \mathrm{~g}^{-1}\right)\end{array}$ & $\begin{array}{c}\text { Vitamin C } \\
\left(\mathrm{mg} 100 \mathrm{~g}-1^{-1}\right)\end{array}$ \\
\hline Control & $11.37 \mathrm{~b}$ & $0.45 \mathrm{~b}$ & $52.33 \mathrm{~b}$ \\
$\mathrm{~K}$ & $12.47 \mathrm{a}$ & $0.44 \mathrm{~b}$ & $75.00 \mathrm{a}$ \\
$\mathrm{Zn}$ & $11.40 \mathrm{~b}$ & $0.51 \mathrm{a}$ & $55.67 \mathrm{~b}$ \\
$\mathrm{Zn}+\mathrm{K}$ & $13.00 \mathrm{a}$ & $0.48 \mathrm{a}$ & $48.00 \mathrm{~b}$ \\
\hline
\end{tabular}

$\mathrm{n}=9$ for the SSC, $\mathrm{pH}$, titratable acidity and vitamin C (three replications $\mathrm{x}$ three different measurements for each replication). Means in columns with the same letter do not differ according to Tukey's test at $\mathrm{P}<0.05$. 
Nasir et al. (2016), reported that $\mathrm{K}$ and $\mathrm{Zn}$ treatments significantly enhanced biochemical traits (SSC, TA, vitamin C and sugar contents) of fruit. These effects may have been the results of the direct incorporation of potassium into the transport of sugars and carbohydrates (Zekri and Obreza, 2009), and the role of zinc in the promotion of various enzymes needed for biochemical reactions and zinc's role in photosynthesis (Alloway, 2008).

As a result, it has been determined that potassium foliar fertilizer can be used to improve quality characteristics such as fruit size, fruit firmness, SSC and vitamin $\mathrm{C}$, and zinc foliar fertilizer can be used to improve quality characteristics such as fruit firmness, fruit color and titratable acidity. It was also found that potassium and zinc form a suitable combination to improve the quality characteristics of the fruit.

\section{References}

Alloway, B.J., 2008. Zinc in Soils and Crop Nutrition, 2nd edn. International Zinc Association, Brussels, 135pp.

Alva, A. K., Mattos, D. J., Paramasivam, S., Patil, B., Dou, H., Sajwan, K.S., 2006. Potassium management for optimizing citrus production and quality. International Journal of Fruit Science, 6 (1): 3-43

Andreini, C., Bertini, I., 2012. A bioinformatics view of zinc enzymes. Journal of Inorganic Biochemistry, 111: 150-156.

Ashraf, M.Y., Yaqub, M., Akhtar, J., Khan, M.A., Khan, M.A., Ebert, G., 2012. Control of excessive fruit drop and improvement in yield and juice quality of Kinnow (Citrus deliciosa $\times$ Citrus nobilis) through nutrient management. Pakistan Journal of Botany, 44: 259265.

Broadley, M.R., White, P.J., Hammond, J.P., Zelko, I., Lux, A., 2007. Zinc in plant. New Phytologist, 173: 677-702.

Dawood, S.A., Meligy, M.S., El-Hamady, M.M., 2001. Influence of zinc sulfhate application on tree, leaf and fruit characters of three young citrus varieties grown on slightly alkaline clay soil. Annals of Agricultural Science, Moshtohor, 39: 433-447.

Durner, E.F., 2013. Principles of Horticultural Physiology. Gutenberg Press Ltd., Tarxien, 393 pp.

El-Baz, E.E.T., 2003. Effect of foliar sprays of zinc and boron on leaf mineral composition: yield and fruit storability of balady mandarin trees. The Journal of Agricultural Science, Mansoura University, 28: 6911-6926.
Eman, A.A., El-Moneim, A., El-Migeed, M.A., Omayma, A., Ismail, M.M., 2007. GA3 and zinc spray for improving yield and fruit quality of 'Washington Navel' orange trees grown under sandy soil conditions. Research Journal of Agriculture and Biological Sciences, 3 (5): 498-503.

Gupta, B., Pathak, G.C., Pandey, N., 2011. Induction of oxidative stress and antioxidant responses in Vigna mungo by zinc stress. Plant Physiology, 58 (1): 8591.

Hacisalihoglu, G., Hart, J.J., Kochian, L.V., 2001. High- and low-affinity zinc transport systems and their possible role in zinc efficiency in bread wheat. Plant Physiology, 125: 456-463.

Hacisalihoglu, G., Hart, J.J., Wang, Y.H., Cakmak, I., Kochian, L.V., 2003. Zinc efficiency is correlated with enhanced expression and activity of zinc-requiring enzymes in wheat. Plant Physiology, 131: 595-602.

Hafez, O.M., El-Metwally, I.M., 2007. Efficiency of zinc and potassium spray alone or in combination with some weed control treatments on weed growth yield and fruit quality of 'Washington Navel' oranges. Journal of Applied Sciences Research, 3 (7): 613-621.

Jeffery, J., Chesters, J., Mills, C., Sadler, P.J., Jornvall, H., 1984. Sorbitol dehydrogenase is a zinc enzyme. EMBO Journal, 3(2): 357-360.

Keshavarz, K., Vahdati, K., Samar, M., Azadegan, B., Brown, P.H., 2011. Foliarapplication of zinc and boron improves walnut vegetative and reproductive growth. Hort Technology, 21 (2): 181-186.

Khayyat, M., Tafazoli, E., Eshghi, S., Rajaee, S., 2007. Effect of nitrogen, boron, potassium and zinc sprays on yield and fruit quality of date palm. AmericanEurasian Journal of Agricultural \& Environmental Sciences 2 (3): 289-296.

Krämer, U., Clemens, S., 2006. "Functions and homeostasis of zinc, copper, and nickel in plants, 215-271". In: Molecular Biology of Metal Homeostasis and Detoxification, (Eds. M.J. Tamás \& E. Martinoia) SpringerVerlag, Berlin, 509 pp.

Lester, G.E., John, L.J., Makus, D.J., 2010. Impact of potassium nutrition on food quality of fruits and vegetables: a condensed and concise review of the literature. Better Crops 94 (1): 18-21.

Liu, K., Huihua, F., Qixin, B., Luan, S., 2000. Inward potassium channel in guard cells as a target for polyamine regulation of stomatal movements. Plant Physiology, 124: 1315-1326.

Malik, R.P., Ahlawat, V.P., Nain, A.S., 2000. Effect of foliar spray of urea and $\mathrm{Zn}$ on yield and fruit quality of 
Kinnow mandarin. Haryana Journal of Horticultural Sciences, 29(1): 37-38.

Marschner, H., 2012. Marschner's Mineral Nutrition of Higher Plants. Elsevier, Academic Press, London, $672 \mathrm{pp}$.

Nasir, M., Khan, A.S., Basra, S.M.A., Malik, A.U., 2016. Foliar application of moringa leaf extract, potassium and zinc influence yield and fruit quality of 'Kinnow'. Scientia Horticulturae, 210: 227-235.

Neilsen, G.H., Hogue, E.J., Neilsen, D., Bowen, P., 2005. Postbloom humic- and fulvic-based zinc sprays can improve apple zinc nutrition. Hort Science, 40 (1): 205-208.

Pandey, N., Pathak, G.C., Sharma, C.P., 2006. Zinc is critically required for pollenfunction and fertilization in lentil. Journal of Trace Elements in Medicine and Biology, 20 (2): 89-96.

Razzaq, K., Khan, A.S., Malik, A.U., Shahid, M., Ullah, S., 2013. Foliar application of zinc influences the leaf mineral status, vegetative and reproductive growth, yield and fruit quality of 'Kinnow' mandarin (Citrus reticulata Blanco.). Journal of Plant Nutrition, 36: 1479-1495.

Rodríguez, V.A., Mazza, S.M., Martínez, G.C., Ferrero, A.R., 2005. $\mathrm{Zn}$ and $\mathrm{K}$ influence in fruit sizes of Valencia orange. Revista Brasileira de Fruticultura, 27 (1): 132-135.

Solar, A., Stampar, F., 2000. Influence of boron and zinc application onflowering and nut set in 'Tonda di
Giffoni' hazelnut. V International Congress on Hazelnut. (30 July 2001, Oregon, United States of America), 307-312.

Tiwari, K.N., 2005. Diagnosing potassium deficiency and maximizing fruit crop production. Better Crop, 89 (4): 29-31.

Usenik, V., Stampar, F., 2002. Effect of foliar application of zinc plus boron on sweet cherry fruit set and yield. Acta Horticiculture, 594: 245-249.

Wang, H., Jin, J.Y., 2005. Photosynthetic rate chlorophyll fluorescence parameters, and lipid peroxidation of maize leaves as affected by zinc deficiency. Photosynthetica, 43 (4): 591-596.

Yan, Z.G., Zhang, Y.Z., Zhang, Y.H., Wang, Y.A., Zhang, F.S., Shu, H.R., 2010. Effects of different zinc application levels on the dynamic accumulation and distribution of dry matter and zinc in apple trees. Plant $\mathrm{Nu}-$ trition and Fertilizer Science, 16 (6): 1402-1409.

Zekri, M., Obreza, T.A., 2009. Plant Nutrients for Citrus Trees. SL 200, Florida Coop. Extension Service, University of Florida's Institute of Food and Agricultural Sciences, 1: 1-5

Zhang, Y., Fu, C.X., Yan, Y.J., Wang, Y.A., Li, M., Chen, M.X., Qian, J.P., Yang, X.T., Cheng, S.H., 2013. Zinc sulfate and sugar alcohol zinc sprays at critical stages to improve apple fruit quality. Hort Technology 23(4): 490-497. 